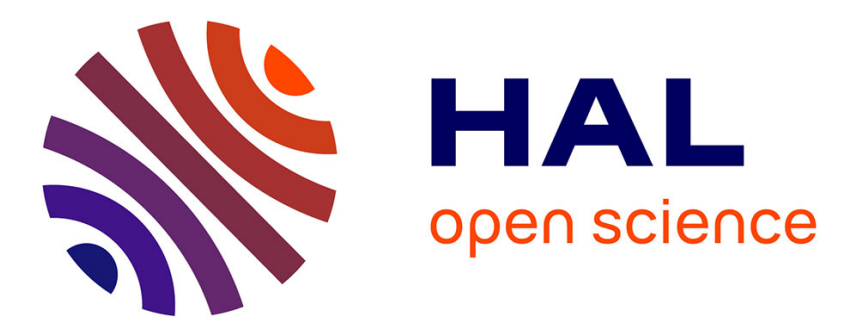

\title{
Solvent-mediated purification of hexa-molybdenum cluster halide, Cs-2[Mo6Cl14] for enhanced optical properties
}

Norio Saito, Pierric Lemoine, Stéphane Cordier, Yoshiki Wada, Takeo

Ohsawa, Noriko Saito, Fabien Grasset, Jeffrey Scott Cross, Naoki Ohashi

\section{To cite this version:}

Norio Saito, Pierric Lemoine, Stéphane Cordier, Yoshiki Wada, Takeo Ohsawa, et al.. Solventmediated purification of hexa-molybdenum cluster halide, Cs-2[Mo6Cl14] for enhanced optical properties. CrystEngComm, 2017, 19 (40), pp.6028-6038. 10.1039/c7ce01440f . hal-01631919

HAL Id: hal-01631919

https://hal-univ-rennes1.archives-ouvertes.fr/hal-01631919

Submitted on 27 Oct 2020

HAL is a multi-disciplinary open access archive for the deposit and dissemination of scientific research documents, whether they are published or not. The documents may come from teaching and research institutions in France or abroad, or from public or private research centers.
L'archive ouverte pluridisciplinaire HAL, est destinée au dépôt et à la diffusion de documents scientifiques de niveau recherche, publiés ou non, émanant des établissements d'enseignement et de recherche français ou étrangers, des laboratoires publics ou privés. 


\section{Solvent-Mediated Purification of Hexa-Molybdenum Cluster Halide, $\mathrm{Cs}_{2}\left[\mathrm{Mo}_{6} \mathrm{Cl}_{14}\right]$ for Enhanced Optical Properties}

Received 00th January 20xx, Accepted 00th January 20xx

DOI: $10.1039 / x 0 x \times 00000 x$

\section{www.rsc.org/}

\author{
Norio Saito ${ }^{a, b, c}$, Pierric Lemoine ${ }^{d}$, Stéphane Cordier $^{d}$, Yoshiki Wadab,e, Takeo Ohsawa ${ }^{b, e}$, Noriko \\ Saito $^{b}$, Fabien Grasset ${ }^{b, c, d}$, Jeffrey Scott Cross ${ }^{a}$, Naoki Ohashi ${ }^{*}, c, e, f$
}

\section{Introduction}

The presence of impurities, such as water molecules and hydroxyl groups, is a possible cause of serious performance degradation and lifetime limitations of electrical and optical materials and structures. In particular, materials with strong ionicities often degrade through the incorporation of water molecules and/or hydroxyl groups. For instance, a number of papers have been published on the effects of moisture on the performance and lifetimes of solar cells involving perovskitetype lead halides. ${ }^{1,2}$ The use of a vacuum chamber at low water vapor pressure is sometimes insufficient to prevent the insertion of water-based impurities in solids, ${ }^{3}$ and heat treatment at high temperature, e.g., $1000{ }^{\circ} \mathrm{C}$, is unable to remove hydroxyl groups from some crystalline solids. ${ }^{4}$ In general, heating is a common and efficient way of dehydrating thermally stable materials. However, materials with poor heat resistances, such as organic/inorganic hybrid systems, decompose even at relatively low temperatures, which are insufficient for dehydration. Hence, it is necessary to consider chemical approaches to prevent water and/or hydroxyl insertion into materials with poor heat resistances. In the present study, we have focused on improving the purities of metal-clustercomplex-based compounds by applying solvent-mediated dehydration techniques in order to observe the intrinsic properties of these compounds and to enhance their optical

\footnotetext{
a. Department of Metallurgy and Ceramics Science, Tokyo Institute of Technology (Tokyo Tech.), 2-12-1 Ookayama, Meguro, Tokyo 152-8551, Japan.

b. National Institute for Materials Science (NIMS), 1-1 Namiki, Tsukuba, Ibaraki 3050044, Japan.

Laboratory for Innovative Key Materials and Structures (LINK; UMI 3629), National Institute for Materials Science, 1-1 Namiki, Tsukuba, Ibaraki 305-0044, Japan.

d. Institut des Sciences Chimiques de Rennes (ISCR; UMR 6226), University of Rennes 1, General Leclerc, Rennes 35042, France.

e. NIMS-Saint-Gobain Center of Excellence for Advanced Materials, NIMS, 1-1 Namiki, Tsukuba, Ibaraki 305-0044, Japan.

f. Materials Research Center for Element Strategy (MCES), Tokyo Institute of Technology, Midori-ku, Yokohama 226-0026, Japan.
}

properties.

The hexamolybdenum cluster halide complexes ( $\left[\mathrm{Mo}_{6} \mathrm{X}_{8}{ }_{8} \mathrm{X}_{6}\right]^{2-}, \mathrm{X}=$ halogen; $\mathrm{i}=$ inner; $\mathrm{a}=$ apical), which are typical metal-cluster-complex-based compounds, have been widely utilized as building blocks not only for solid-state inorganic compounds, ${ }^{5-7}$ but also supramolecular assemblies ${ }^{8,9}$ and nanostructures, particularly organic/inorganic hybrid systems. ${ }^{10,11}$ Since the size of a $\left[\mathrm{Mo}_{6} \mathrm{X}_{8}{ }_{8} \mathrm{X}_{6}{ }_{6}\right]^{2-}$ complex is much larger $(\sim 1 \mathrm{~nm})$ than an ordinary complex, and these complexes possess good solubilities in a variety of organic solvents, crystallization of $\left[\mathrm{Mo}_{6} \mathrm{X}_{8}{ }_{8} \mathrm{X}_{6}^{\mathrm{a}}\right]^{2-}$ complexes involving organic counter cations ${ }^{12-14}$ have been widely studied with the aim of functionalizing these compounds. One of the notable functions of a $\left[\mathrm{Mo}_{6} \mathrm{X}_{8}{ }_{8} \mathrm{X}_{6}\right]^{2-}$ complex is broadband red luminescence under excitation with blue or UV illumination. ${ }^{15-17}$ As such, the luminescence properties of these complexes are compatible with blue-LED-based solid-state lighting devices; however, their luminescence efficiencies as well as stabilities need to be improved before they can be used in practical devices.

As $\left[\mathrm{Mo}_{6} \mathrm{X}_{8}{ }_{8} \mathrm{X}_{6}{ }^{\mathrm{a}}\right]^{2-}$-complex-based crystals have large interstitial spaces in their lattices, the insertion of impurity molecules into these lattices is possible. Hence, the intercalation of impurity molecules is a potential cause of the degradation of the physical properties and stabilities of these materials, although it has not been well evaluated. While the trigonal form of $P \overline{3} 1 c$ symmetry (Fig. 1(a)) is the stable form of $\mathrm{Cs}_{2}\left[\mathrm{Mo}_{6} \mathrm{X}_{14}\right]$ at room temperature, ${ }^{18-20}$ recrystallization of $\mathrm{Cs}_{2}\left[\mathrm{Mo}_{6} \mathrm{X}_{14}\right]$ in solvents such as acetone often results in the formation of the monoclinic form rather than the trigonal form. ${ }^{18,19}$ The formation of the monoclinic form has been attributed to the intercalation of water molecules and the monoclinic phase was recently identified to be $\mathrm{Cs}_{2}\left[\mathrm{Mo}_{6} \mathrm{Cl}_{14}\right] \cdot \mathrm{H}_{2} \mathrm{O}$ and belongs to the $C 2 / c$ space group (Fig. 1(b)). ${ }^{19}$ It is also notable that the lattice parameters of trigonal $\mathrm{Cs}_{2}\left[\mathrm{Mo}_{6} \mathrm{Cl}_{14}\right]$ vary with preparation conditions, ${ }^{18,21,22}$ and such variations in lattice parameters are likely due to the insertion of water molecules at the interstitial positions of the trigonal lattice. ${ }^{18}$ As disorder in a crystalline lattice potentially causes 
the degradation of its luminescence properties, it is necessary to prepare cluster-complex compounds of very high purity, i.e., low concentrations of water impurities, and to investigate the effects of purity on their luminescence properties in order to further improve luminescence efficiency.

In this context, we realize that the synthesis of pure $\mathrm{Cs}_{2}\left[\mathrm{Mo}_{6} \mathrm{X}_{8} \mathrm{X}_{6}^{\mathrm{a}}{ }_{6}\right]$ is of great importance for the research and development of these compounds. Hence, in this study, recrystallization experiments that explored efficient ways of obtaining high-purity $\mathrm{Cs}_{2}\left[\mathrm{Mo}_{6} \mathrm{Cl}_{14}\right]$, free from water impurities, have been performed. In particular, three alcohols, methanol $(\mathrm{MeOH})$, ethanol $(\mathrm{EtOH})$, and 1-propanol (1-PrOH) were used as solvents, and the recrystallization behavior of $\mathrm{Cs}_{2}\left[\mathrm{Mo}_{6} \mathrm{Cl}_{14}\right]$ in these solvents was investigated. Here, we assume that the strong hydrophilicity of the alcohol traps water molecules in the solvent and induces the crystallization of water-free $\mathrm{Cs}_{2}\left[\mathrm{Mo}_{6} \mathrm{Cl}_{14}\right]$. In order to provide evidence of the watertrapping ability of these alcohols, we used two types of precursors for the crystallization of $\mathrm{Cs}_{2}\left[\mathrm{Mo}_{6} \mathrm{Cl}_{14}\right]$. One is trigonal $\mathrm{Cs}_{2}\left[\mathrm{Mo}_{6} \mathrm{Cl}_{14}\right]$ and is of relatively low water content, and the other is monoclinic $\mathrm{Cs}_{2}\left[\mathrm{Mo}_{6} \mathrm{Cl}_{14}\right] \cdot \mathrm{H}_{2} \mathrm{O}$ and contains water molecules in its crystal structure. As a result, we found that trigonal $\mathrm{Cs}_{2}\left[\mathrm{Mo}_{6} \mathrm{Cl}_{14}\right]$, devoid of water contamination, can be obtained using EtOH or 1-PrOH as the recrystallization solvent. The purification mechanism will be discussed in light of thermal and optical characterizations of compounds crystallized in different solvents.

\section{Experimental}

\subsection{Precursors}

Two kinds of $\left[\mathrm{Mo}_{6} \mathrm{Cl}_{14}\right]^{2-}$-complex-based compound, $\mathrm{Cs}_{2}\left[\mathrm{Mo}_{6} \mathrm{Cl}_{14}\right] \cdot \mathrm{H}_{2} \mathrm{O}$ and $\mathrm{Cs}_{2}\left[\mathrm{Mo}_{6} \mathrm{Cl}_{14}\right]$ were prepared as precursors for the recrystallization experiments. Here, monoclinic $\mathrm{Cs}_{2}\left[\mathrm{Mo}_{6} \mathrm{Cl}_{14}\right] \cdot \mathrm{H}_{2} \mathrm{O}$ was selected as the watercontaining precursor in order to examine the effect of solvent on the preparation of trigonal water-free $\mathrm{Cs}_{2}\left[\mathrm{Mo}_{6} \mathrm{Cl}_{14}\right]$. Preparation of trigonal $\mathrm{Cs}_{2}\left[\mathrm{Mo}_{6} \mathrm{Cl}_{14}\right]$ and monoclinic $\mathrm{Cs}_{2}\left[\mathrm{Mo}_{6} \mathrm{Cl}_{14}\right] \cdot \mathrm{H}_{2} \mathrm{O}$ was conducted as described previously. ${ }^{19,22,23}$ Preparation methods of the precursors are described in the supporting information.

Hereafter, crystalline phases having structures similar to $\mathrm{Cs}_{2}\left[\mathrm{Mo}_{6} \mathrm{Cl}_{14}\right] \cdot \mathrm{H}_{2} \mathrm{O}$ and belonging to the monoclinic $C 2 / c$ space group are referred to as the 'monoclinic phase' or 'monoclinic form', while phases of structure similar to $\mathrm{Cs}_{2}\left[\mathrm{Mo}_{6} \mathrm{Cl}_{14}\right]$ belonging to the trigonal $P \overline{3} 1 c$ space group are abbreviated to 'trigonal phase' or 'trigonal form' for convenience.

\subsection{Recrystallization experiments}

Purification of trigonal $\mathrm{Cs}_{2}\left[\mathrm{Mo}_{6} \mathrm{Cl}_{14}\right]$ by removal of residual water was examined as follows. Firstly, we prepared suspensions of trigonal $\mathrm{Cs}_{2}\left[\mathrm{Mo}_{6} \mathrm{Cl}_{14}\right]$ or monoclinic $\mathrm{Cs}_{2}\left[\mathrm{Mo}_{6} \mathrm{Cl}_{14}\right] \cdot \mathrm{H}_{2} \mathrm{O}$ in the alcohols. Accordingly, the precursor powder, $\mathrm{Cs}_{2}\left[\mathrm{Mo}_{6} \mathrm{Cl}_{14}\right]$ or $\mathrm{Cs}_{2}\left[\mathrm{Mo}_{6} \mathrm{Cl}_{14}\right] \cdot \mathrm{H}_{2} \mathrm{O}(80 \mathrm{mg})$, was dispersed in $1.0 \mathrm{~mL}$ of methanol $(\mathrm{MeOH})$, ethanol $(\mathrm{EtOH})$, or 1-propanol (1-PrOH) in glass vessels. As mentioned below, while some of each precursor dissolved in the solvent, a residual amount of solid remained in the solvent, which is why the term "suspension" is used in this report. Each suspension was stirred at $200 \mathrm{rpm}$ at $25^{\circ} \mathrm{C}$ in a glove box filled with dry $\mathrm{N}_{2}$ gas to prevent unintentional incorporation of water molecules from the environment. After stirring for $10 \mathrm{~min}, 30$ $\min , 2 \mathrm{~h}$, or $12 \mathrm{~h}$, the suspensions were centrifuged at $5000 \mathrm{rpm}$ for $3 \mathrm{~min}$ to separate the remaining solids in the suspensions. Unless otherwise stated, the results detailed below refer to samples collected after stirring for $12 \mathrm{~h}$. Each solid obtained in this manner was dried under vacuum in a desiccator for subsequent characterization.

During stirring for $12 \mathrm{~h}$, the state of each suspension was monitored by measuring the time evolution of $\left[\mathrm{Mo}_{6} \mathrm{Cl}_{14}\right]^{2-}$ complex solubility in every solvent. The supernatant liquid (20 $\mu \mathrm{L}$ ) was collected from each suspension for optical absorption measurements. The collected solvents were diluted with EtOH and the concentration of the $\left[\mathrm{Mo}_{6} \mathrm{Cl}_{14}\right]^{2-}$ complex was determined by ultraviolet-visible absorbance as described in the supporting information (Fig. S1).

\subsection{Characterizations and analyses}

Crystalline phases in the powders before and after recrystallization were identified by powder X-ray diffraction (XRD). The observed profiles were indexed by comparison with simulated profiles generated by the RIETAN-FP program $^{24}$ on the basis of the structural parameters of $\mathrm{Cs}_{2}\left[\mathrm{Mo}_{6} \mathrm{Cl}_{14}\right]$ in its trigonal form, ${ }^{18,19}$ and $\mathrm{Cs}_{2}\left[\mathrm{Mo}_{6} \mathrm{Cl}_{14}\right] \cdot \mathrm{H}_{2} \mathrm{O}$ in its monoclinic form. ${ }^{19}$ The parameters used for these simulations are summarized in Tables $\mathrm{S} 1$ and $\mathrm{S} 2$ in the supporting information. In order to identify the molecules incorporated into the samples, thermal desorption spectroscopy (TDS) and Fourier transform infrared spectroscopy (FT-IR) were conducted on each sample. In addition, optical properties, photoluminescence (PL) and time-resolved-photoluminescence (TRPL) spectra, were acquired in order to determine the effect of purification on physical properties. The observed TRPL profiles were fitted to exponential decay functions to evaluate luminescence lifetimes. Details of these characterizations can be referred in the supporting information.

\subsection{Calculations}

The electronic structures of the trigonal and monoclinic phases were studied by density functional theory (DFT) calculations. In particular, a revision of the generalized gradient approximation, PBE-Sol, ${ }^{25}$ implemented in a plane-wave based pseudo-potential calculation code, the CASTEP code, ${ }^{26}$ was selected for the simulation study. The calculation conditions are similar to those used in our previous study; ${ }^{27}$ however, in the present study, relativistic effects were included through the use of pseudo-potentials generated by a procedure developed by Koelling and Harmon. ${ }^{28}$ Stable lattice parameters were obtained by geometry optimization calculations and, subsequently, energy band structures ( $E-k$ dispersions), densities-of-states (DOSs), and projected-densities-of-states (PDOSs) of the relaxed structures were calculated. Details of the methods used 
during the DFT simulations are described in the supporting information.

\section{Results and discussion}

\subsection{Identification of reaction products}

\subsubsection{Precursors}

The monoclinic-phase precursor was clearly obtained as a single phase. On the other hand, the powder prepared with the aim of obtaining the trigonal phase contained significant amounts of the monoclinic phase. Subsequent heat treatment at $150{ }^{\circ} \mathrm{C}$ induced transformation of the residual monoclinic phase to the trigonal phase but very small amount of the monoclinic phase was remained. As perfect removal of monoclinic phase was not achieved in this study, the trigonal phase powder heated at $150{ }^{\circ} \mathrm{C}$ is regarded as a precursor of the trigonal phase in which the concentration of water is clearly lower than the precursor of the monoclinic phase. The detailed results of phase identification for the prepared precursor compounds are described in the supporting information (see Fig. S2).

As previously reported, it is noteworthy that the monoclinic phase decomposed to the trigonal phase during storage. ${ }^{19}$ The XRD pattern shown in Fig. S2(c) was obtained from a sample of the prepared monoclinic-phase powder that was kept for more than 4 weeks in a dry atmosphere; it is clear that the sample had evolved into the trigonal form, $\mathrm{Cs}_{2}\left[\mathrm{Mo}_{6} \mathrm{Cl}_{14}\right]$. This indicates that the monoclinic phase, $\mathrm{Cs}_{2}\left[\mathrm{Mo}_{6} \mathrm{Cl}_{14}\right] \cdot \mathrm{H}_{2} \mathrm{O}$, is not very stable in a dry atmosphere. However, the complete decomposition of the monoclinic phase to pure $\mathrm{Cs}_{2}\left[\mathrm{Mo}_{6} \mathrm{Cl}_{14}\right]$ by thermal treatment was not successful, as evidenced by the XRD pattern shown in Fig. S2(e). Hence, these results are good examples that demonstrate the difficulty in dehydrating $\mathrm{Cs}_{2}\left[\mathrm{Mo}_{6} \mathrm{Cl}_{14}\right]$.

\subsubsection{Solids collected from the suspensions}

Here, we discuss the powder collected from suspensions of the $\left[\mathrm{Mo}_{6} \mathrm{Cl}_{14}\right]^{2-}$ complexes in alcohol solvents after stirring for $12 \mathrm{~h}$. It is noteworthy that the amount of precursor dispersed in each solvent was enough to maintain solids in the suspension; in other words the amount of precursor dispersed in the solvent exceeded its solubility. The XRD pattern of the powder collected from each suspension is shown in Fig. 2, which compares the XRD patterns acquired from powders obtained using different precursors. For the suspension in EtOH, the collected powder was identified to be the trigonal phase regardless of the precursor dispersed in the solvent, as shown in Fig. 2(a). It is interesting to note that the trigonal phase, i.e., $\mathrm{Cs}_{2}\left[\mathrm{Mo}_{6} \mathrm{Cl}_{14}\right]$, crystallized in the suspension even when the monoclinic phase, i.e., $\mathrm{Cs}_{2}\left[\mathrm{Mo}_{6} \mathrm{Cl}_{14}\right] \cdot \mathrm{H}_{2} \mathrm{O}$, was used. This means that water molecules are removed from the crystal structure leading to its transformation from the monoclinic phase to the trigonal phase in the EtOH suspension. Similar behavior was observed for the 1-PrOH suspension. In fact, the powder collected from the 1-PrOH suspension was uniquely trigonal phase regardless of the crystalline form of the precursor, as shown in Fig. 2(b). It should be noted that reproducibility was not very high when $1-\mathrm{PrOH}$ was used as the solvent. Indeed, in some experiments, the transformation from $\mathrm{Cs}_{2}\left[\mathrm{Mo}_{6} \mathrm{Cl}_{14}\right] \cdot \mathrm{H}_{2} \mathrm{O}$ to $\mathrm{Cs}_{2}\left[\mathrm{Mo}_{6} \mathrm{Cl}_{14}\right]$ was not complete after stirring for $12 \mathrm{~h}$, suggestive of a kinetic effect. This kinetics issue will be discussed in the latter part of this section.

On the other hand, the results for the $\mathrm{MeOH}$ suspensions are opposite to those involving EtOH and 1-PrOH; the solid collected from the $\mathrm{MeOH}$ suspension was identified to be the monoclinic phase, as seen in Fig. 2(c). From the XRD patterns in this figure, the presence of a trace amount of the trigonal phase, $2 \theta=12.12^{\circ}$, is present in the sample collected from the suspension prepared with the trigonal-phase precursor (Fig. 2(c)). It is interesting to note that the use of acetone for purification resulted in the formation of a mixed phase, containing both monoclinic and trigonal phases, while the use of the alcohol solvents in this study enabled single phases, i.e., trigonal using EtOH or 1-PrOH, and monoclinic using $\mathrm{MeOH}$, to be obtained. These results indicate that the selective growth of either single trigonal or monoclinic-phase samples can be achieved using an appropriate recrystallization solvent.

The lattice parameters of the recrystallized trigonal phases determined from the XRD results by the least square method (Table 1) indicate that the unit cell volumes of the trigonal phases recrystallized from EtOH and 1-PrOH are smaller than that of the trigonal-phase precursor. The smaller unit cell volume is due to the relatively small $a$-axis length. In particular, the lattice parameters of the precipitates collected from the 1PrOH suspensions were almost identical irrespective of whether the monoclinic or trigonal-phase precursor was used. On the other hand, the unit cell volume of the trigonal phase obtained from the EtOH suspensions is slightly, but evidently, larger than that obtained from the trigonal phase collected from the 1PrOH suspensions. In addition, the unit cell volume of the trigonal phase recrystallized from EtOH depended on the precursor. In fact, the unit cell volume of the sample collected from the EtOH suspension was larger when crystallized using $\mathrm{Cs}_{2}\left[\mathrm{Mo}_{6} \mathrm{Cl}_{14}\right] \cdot \mathrm{H}_{2} \mathrm{O}$ as the precursor. As mentioned in our previous report, ${ }^{18}$ expansion of the trigonal-phase lattice is attributable to the insertion of impurities, such as water molecules. Hence, we presume that crystallization from 1$\mathrm{PrOH}$ as the solvent is the appropriate way of achieving a highpurity trigonal phase. The use of EtOH as solvent is also a possible way of obtaining a single-phase powder of the trigonal phase, however the slightly larger lattice parameters observed for the sample recrystallized from EtOH suggests that the use of 1-PrOH as the solvent has advantages during the purification of the trigonal phase. The following discussion on the TDS and FT-IR results supports this hypothesis; particularly how the behavior of the lattice parameters correlates with the presence of water molecules inserted into the lattice of trigonal phase.

Figure 3 depicts the normalized TDS profile of the trigonalphase sample collected from $\mathrm{EtOH}$, which exhibits three major desorption peaks. Peaks centered at $183{ }^{\circ} \mathrm{C}$ are associated with fragments with $m / z=15$, which corresponds to $\left[{ }^{12} \mathrm{C}^{1} \mathrm{H}_{3}\right]$, and $m / z=46$, which corresponds $\left[{ }^{12} \mathrm{C}_{2}{ }^{1} \mathrm{H}_{6}{ }^{16} \mathrm{O}\right]$. Hence, the peak at $183{ }^{\circ} \mathrm{C}$ is attributed to the desorption of $\mathrm{EtOH}$. On the other hand, the peaks observed at $132{ }^{\circ} \mathrm{C}$ and $236{ }^{\circ} \mathrm{C}$ are dominated 
by fragments with $m / z=18$, corresponding to $\left[{ }^{1} \mathrm{H}_{2}{ }^{16} \mathrm{O}\right]$, and $m / z$ $=16$, corresponding to $\left[{ }^{16} \mathrm{O}\right]$ and/or $\left[{ }^{12} \mathrm{C}^{1} \mathrm{H}_{4}\right]$. As the signal at $m / z=12$, corresponding to the $\left[{ }^{12} \mathrm{C}\right]$ fragment, had no peak at $236{ }^{\circ} \mathrm{C}$, it is presumed that the $\mathrm{m} / \mathrm{z}=16$ peak at $236{ }^{\circ} \mathrm{C}$ does not correspond to $\left[\mathrm{CH}_{4}\right]$, but rather to the $[\mathrm{O}]$ fragment. With these assignments, the peaks at $132{ }^{\circ} \mathrm{C}$ and $236{ }^{\circ} \mathrm{C}$ are attributed to the desorption of water; it is likely that the peak at $132{ }^{\circ} \mathrm{C}$ corresponds to surface adsorbates, and that at $236{ }^{\circ} \mathrm{C}$ to water molecules inserted into the lattice of the trigonal phase. This assignment is consistent to the XRD results. Indeed, the lattice parameters of the trigonal phase collected from EtOH vary slightly with preparation conditions, as indicated in Table 1, and the origin of this variation is attributed to lattice expansion resulting from the insertion of water molecules.

The TDS profile of the trigonal-phase powder collected from 1-PrOH also exhibits three peaks, as shown in Fig. S3(a) in the supporting information, however this profile differs from that of the sample prepared using EtOH. The assignment of those desorption peaks (see supporting information) indicated that the trigonal-phase powder collected from 1-PrOH does not show any trace of water desorption from its crystalline lattice, although the sample prepared with EtOH showed evidence of water desorption, as described above; this assignment is also consistent with the XRD results. Although signal for $m / z=18$ fragment was found in TDS spectra of the sample prepared in 1-PrOH suspension, that was identified to be a fragment caused by decomposition of alcohol molecule ${ }^{29}$ not to be a fragment from water molecule. Indeed, the trigonal phase collected from 1-PrOH exhibits the smallest lattice parameters, which is attributable to very low concentrations of intercalated water. Hence, we presume that water intercalation into the trigonal form is preferentially suppressed when 1-PrOH is used as the recrystallization solvent.

The TDS spectra of the monoclinic phase prepared using $\mathrm{MeOH}$ and assignments for the observed desorption peaks are also shown in Fig. S3(b) in the supporting information. As this sample was identified to be $\mathrm{Cs}_{2}\left[\mathrm{Mo}_{6} \mathrm{Cl}_{14}\right] \cdot \mathrm{H}_{2} \mathrm{O}$, we expected to see a significant desorption of water molecules. However, the $m / z=18$ signal intensity for this material was much lower than that observed for the trigonal phase prepared using EtOH as described in the supporting information. With these assignments in mind, it is very likely that the water molecules in $\mathrm{Cs}_{2}\left[\mathrm{Mo}_{6} \mathrm{Cl}_{14}\right] \cdot \mathrm{H}_{2} \mathrm{O}$ are not removed during this TDS analysis; we presume that the emission of water from solids collected from the various suspensions are only visible for the trigonal phase collected from EtOH. Very week desorption signal at $m / z=18$ for the sample prepared in $\mathrm{MeOH}$ suspension will be discussed in relation with the results of FT-IR measurements. Summarizing the results of TDS measurement, it was confirmed that water concentration in the sample prepared in 1-PrOH suspension was very low compared to that prepared in the EtOH suspension.

Figure 4 summarizes the FT-IR spectra for the samples prepared from the different precursors in the different solvents We first focus on the absorptions observed around 3350-3700 $\mathrm{cm}^{-1}$ shown in Fig. 4(a); these bands are attributed to various O$\mathrm{H}$ stretching (OH-s) modes. ${ }^{30-33}$ In this figure, it is evident that the monoclinic phase prepared from $\mathrm{MeOH}$ exhibits a sharp and intense peak centered at $3572 \mathrm{~cm}^{-1}$. This peak appears to be associated with shoulders at around 3621 and $3492 \mathrm{~cm}^{-1}$. According to previous reports, ${ }^{33-35}$ the $\mathrm{OH}-\mathrm{s}$ mode frequency is sensitive to structural restrictions and tends to decease with increasing restrictive forces. Hence, the set of three peaks at 3621,3572 , and $3492 \mathrm{~cm}^{-1}$ are attributable to water molecules incorporated into the monoclinic phase.

Interestingly, the OH-s band at $3640 \mathrm{~cm}^{-1}$ is relatively pronounced and the other two peaks at around 3572 and 3492 $\mathrm{cm}^{-1}$ are relatively suppressed in the spectrum of the trigonal precursor crystalized using acetone as solvent, which corresponds to the sample described in the supporting information (Fig. S2(d)) in which the monoclinic phase was detected as an impurity. As the $\mathrm{OH}-\mathrm{s}$ mode frequency tends to decease with increasing restrictive forces, ${ }^{33-35}$ we conclude that water molecules inserted into the trigonal phase are rather free, while hydrogen bonding between $\mathrm{Cl}$ and water is likely to be stronger in the monoclinic phase.

On the other hand, the FT-IR profiles of the OH-s spectral regions of the trigonal phase prepared with $\mathrm{EtOH}$ and 1-PrOH were weak and broadened. Indeed, the two broad peaks found at around $3290-3500 \mathrm{~cm}^{-1}$ are characteristic of the trigonal phase prepared with EtOH and 1-PrOH..$^{32,34}$ The FT-IR spectra of trigonal-phase precursor recrystallized from acetone possess between the monoclinic phase prepared using $\mathrm{MeOH}$, and the trigonal phase prepared with EtOH or 1-PrOH. This means that while the set of peaks at 3640,3572 , and $3492 \mathrm{~cm}^{-1}$ was observed in the spectrum of the precursor prepared with acetone, and which dominates the spectrum of the trigonal phase, the two peaks at around $3290-3500 \mathrm{~cm}^{-1}$ are absent in the monoclinic phase prepared using $\mathrm{MeOH}$.

Similar behavior was observed in the $\mathrm{O}-\mathrm{H}$ bending $(\mathrm{OH}-\mathrm{b})$ mode region, as shown in Fig. 4(b). According to the literature, peaks at around $1600 \mathrm{~cm}^{-1}$ are assignable to OH-b modes. ${ }^{30,33} \mathrm{~A}$ sharp peak at $1612 \mathrm{~cm}^{-1}$ is observed in the spectrum of the monoclinic phase prepared using $\mathrm{MeOH}$, while peaks at 1595 $1601 \mathrm{~cm}^{-1}$ are observed in the spectrum of the trigonal phase prepared using EtOH or 1-PrOH. Looking at the FT-IR peak profile for the trigonal precursor prepared with acetone, a broad peak with long tails to both lower and higher frequencies is observed. This feature is likely to be due to the presence of the monoclinic phase as a minor impurity, and the presence of water incorporated into the trigonal phase. Summarizing the FT-IR observations in the OH-s and OH-b ranges, it is clear that the states of the $\mathrm{OH}$ groups, likely to be associated with water molecules, are different in the trigonal and monoclinic phases and, interestingly, the trigonal-phase precursor containing a minor amount of the monoclinic phase exhibited behavior intermediate between pure monoclinic and trigonal phases.

Figure 4(b) also compares the FT-IR spectra of the OH-b mode ranges for samples before and after the TDS experiments. Firstly, it is interesting to note that the FT-IR spectrum of the monoclinic phase prepared using $\mathrm{MeOH}$ exhibited no obvious change after heating under vacuum during the TDS analysis. This indicates that water molecules associated with the 
monoclinic phase were not removed by heating under vacuum. Indeed, the position of the peak at $1612 \mathrm{~cm}^{-1}$ was unchanged after TDS. The XRD profile of the monoclinic-phase powder after TDS could not be assigned because the pattern was completely different to that from either the monoclinic or trigonal phase. We conclude that the monoclinic phase is transformed into another crystal structure that retained water molecules in its lattice even after TDS, and is consistent with TDS results that show insignificant water desorption.

On the other hand, the spectral profile of the OH-b mode of the trigonal phase prepared with 1-PrOH had almost disappeared after heating under vacuum. This is different from the behavior of the trigonal phase crystallized from EtOH, in which the peak at $1601 \mathrm{~cm}^{-1}$ was observed to decrease upon heating under vacuum, but was still significantly present. As peaks around 1595-1612 $\mathrm{cm}^{-1}$ are commonly found in both monoclinic and trigonal phases, we attribute the peak at around $1610 \mathrm{~cm}^{-1}$ to water molecules inserted in the $\left[\mathrm{Mo}_{6} \mathrm{Cl}_{14}\right]^{2-}$ complex lattice. Hence, the presence of a small water-related peak in the spectrum of the trigonal phase prepared with EtOH is consistent with the fact that water desorption was observed from this sample in the TDS experiment presented in Fig. 3. Here, the FT-IR results support those obtained by XRD. As mentioned, the trigonal phase prepared with EtOH and 1-PrOH exhibited smaller lattice parameters that were dependent on the precursor compound. On the other hand, the trigonal precursor prepared using acetone exhibits a relatively large unit cell, with cell parameters that depended on the preparation conditions. ${ }^{18}$ The FT-IR results reveal that $\mathrm{OH}-\mathrm{s}$ and $\mathrm{OH}-\mathrm{b}$ modes were pronounced in the samples prepared with acetone or $\mathrm{MeOH}$ as solvent, but were minor in the samples prepared with EtOH or 1-PrOH. Hence, we attribute these variations in the lattice parameters of the trigonal phase to variation in the amount of water incorporated into the trigonal-phase lattice. As the TDS experiments also revealed the absence of water desorption from the trigonal $\mathrm{Cs}_{2}\left[\mathrm{Mo}_{6} \mathrm{Cl}_{14}\right]$ prepared with $1-\mathrm{PrOH}$, we can safely conclude that the preparation of a high-purity trigonal phase devoid of inserted water molecules is favoured by $1-\mathrm{PrOH}$ as solvent.

Presence of residual alcohol related molecule is another important issue. As described in the supporting information (Fig. S4), extra peaks relating to residual alcohol related modes were clearly seen in the spectra for the sample collected from EtOH and 1-PrOH suspension. Those results supports identification of TDS profile shown above.

\subsection{Kinetics and mechanism of recrystallization and dehydration}

The results discussed above indicate that solvent-mediated purification, i.e., the formation of a single-phase powder of the dehydrated trigonal phase, is possible by the appropriate choice of recrystallization solvent. We now discuss the kinetics and mechanism of the purification process, through time-evolution experiments. Figure 5 shows the evolution of the $\left[\mathrm{Mo}_{6} \mathrm{Cl}_{14}\right]^{2-}$ concentration in the supernatants of the suspensions with time, in which six curves with different precursor/solvent combinations are depicted. First, we focus on the results for
$\mathrm{MeOH}$ as the solvent. The $\left[\mathrm{Mo}_{6} \mathrm{Cl}_{14}\right]^{2-}$ concentration in the supernatant of the $\mathrm{Cs}_{2}\left[\mathrm{Mo}_{6} \mathrm{Cl}_{14}\right] / \mathrm{MeOH}$ combination decreased with time, while that for the $\mathrm{Cs}_{2}\left[\mathrm{Mo}_{6} \mathrm{Cl}_{14}\right] \cdot \mathrm{H}_{2} \mathrm{O} / \mathrm{MeOH}$ combination remained constant during the stirring time. After stirring for $5 \mathrm{~h}$, the $\left[\mathrm{Mo}_{6} \mathrm{Cl}_{14}\right]^{2-}$ concentration for the $\mathrm{Cs}_{2}\left[\mathrm{Mo}_{6} \mathrm{Cl}_{14}\right] / \mathrm{MeOH}$ combination converged to that of the $\mathrm{Cs}_{2}\left[\mathrm{Mo}_{6} \mathrm{Cl}_{14}\right] \cdot \mathrm{H}_{2} \mathrm{O} / \mathrm{MeOH}$ combination. In other words, transient solubility behavior was observed for the $\mathrm{Cs}_{2}\left[\mathrm{Mo}_{6} \mathrm{Cl}_{14}\right] / \mathrm{MeOH}$ combination, where the solid phase in the suspension transformed from the monoclinic phase to the trigonal phase. On the other hand, the opposite behavior was observed when EtOH was used as solvent. Indeed, the concentration of $\left[\mathrm{Mo}_{6} \mathrm{Cl}_{14}\right]^{2-}$ in the supernatant of the $\mathrm{Cs}_{2}\left[\mathrm{Mo}_{6} \mathrm{Cl}_{14}\right] \cdot \mathrm{H}_{2} \mathrm{O} / \mathrm{EtOH}$ combination decreased with time, while that for the $\mathrm{Cs}_{2}\left[\mathrm{Mo}_{6} \mathrm{Cl}_{14}\right] / \mathrm{EtOH}$ combination remained constant, irrespective of stirring time. The $\left[\mathrm{Mo}_{6} \mathrm{Cl}_{14}\right]^{2-}$ concentration in the supernatant of the $\mathrm{Cs}_{2}\left[\mathrm{Mo}_{6} \mathrm{Cl}_{14}\right] \cdot \mathrm{H}_{2} \mathrm{O} / \mathrm{EtOH}$ combination converged to the value for the $\mathrm{Cs}_{2}\left[\mathrm{Mo}_{6} \mathrm{Cl}_{14}\right] / \mathrm{EtOH}$ combination after stirring for $12 \mathrm{~h}$. The observed transient behavior in the $\mathrm{Cs}_{2}\left[\mathrm{Mo}_{6} \mathrm{Cl}_{14}\right] \cdot \mathrm{H}_{2} \mathrm{O} / \mathrm{EtOH}$ combination corresponds to the transformation from the monoclinic phase to the trigonal phase.

The evolution of solubility in the 1-PrOH solvent with time was similar to that observed for the EtOH solvent. Indeed, the solubility of $\left[\mathrm{Mo}_{6} \mathrm{Cl}_{14}\right]^{2-}$ in the supernatant of the $\mathrm{Cs}_{2}\left[\mathrm{Mo}_{6} \mathrm{Cl}_{14}\right] \cdot \mathrm{H}_{2} \mathrm{O} / 1-\mathrm{PrOH}$ combination gradually decreased with time, in a similar fashion to that observed for the $\mathrm{Cs}_{2}\left[\mathrm{Mo}_{6} \mathrm{Cl}_{14}\right] \cdot \mathrm{H}_{2} \mathrm{O} / \mathrm{EtOH}$ combination. The solubility of the $\mathrm{Cs}_{2}\left[\mathrm{Mo}_{6} \mathrm{Cl}_{14}\right] / 1-\mathrm{PrOH}$ combination appears to be not very stable and remained lower than that of the $\mathrm{Cs}_{2}\left[\mathrm{Mo}_{6} \mathrm{Cl}_{14}\right] \cdot \mathrm{H}_{2} \mathrm{O} / 1$ $\mathrm{PrOH}$ combination. Scatter in the $\left[\mathrm{Mo}_{6} \mathrm{Cl}_{14}\right]^{2-}$ solubility data for the $\mathrm{Cs}_{2}\left[\mathrm{Mo}_{6} \mathrm{Cl}_{14}\right] / 1-\mathrm{PrOH}$ combination with time was due to technical difficulties, as the very low solubility of $\left[\mathrm{Mo}_{6} \mathrm{Cl}_{14}\right]^{2-}$ in the 1-PrOH solvent causes results in a low signal/noise ratio upon measurement. While the $\left[\mathrm{Mo}_{6} \mathrm{Cl}_{14}\right]^{2-}$ solubility of the $\mathrm{Cs}_{2}\left[\mathrm{Mo}_{6} \mathrm{Cl}_{14}\right] \cdot \mathrm{H}_{2} \mathrm{O} / \mathrm{EtOH}$ combination converged to that for the $\mathrm{Cs}_{2}\left[\mathrm{Mo}_{6} \mathrm{Cl}_{14}\right] / \mathrm{EtOH}$ combination, as mentioned above, the $\left[\mathrm{Mo}_{6} \mathrm{Cl}_{14}\right]^{2-}$ solubility for the $\mathrm{Cs}_{2}\left[\mathrm{Mo}_{6} \mathrm{Cl}_{14}\right] \cdot \mathrm{H}_{2} \mathrm{O} / 1-\mathrm{PrOH}$ combination remained higher than that for the $\mathrm{Cs}_{2}\left[\mathrm{Mo}_{6} \mathrm{Cl}_{14}\right] / 1$ $\mathrm{PrOH}$ combination, even after stirring for $12 \mathrm{~h}$.

Here, we attribute the transient solubility behavior to the dependency of the partition coefficient between water and the solvent, and the solid in suspension. It is likely that water molecules are more stable when dissolved in 1-PrOH or EtOH than when inserted into solids, while we assume the water molecules inserted into solids are more stable than those dissolved in $\mathrm{MeOH}$. Hence, the transient solubility behavior is attributed to the recovery from an unstable state to stable state by removal of water molecules from the solid, or by intercalating water molecules into the solid. In the case of $\mathrm{MeOH}$, once trigonal-phase $\left[\mathrm{Mo}_{6} \mathrm{Cl}_{14}\right]^{2-}$ is dissolved in the solvent it enables crystallization of the monoclinic phase by trapping residual water molecules from the solvent. On the other hand, in the case of EtOH and 1-PrOH, once the monoclinic-phase $\left[\mathrm{Mo}_{6} \mathrm{Cl}_{14}\right]^{2-}$ is dissolved in the solvent it enables crystallization of the trigonal phase by releasing water 
molecules into the solvent. This explains the observed transient solubility behavior.

For 1-PrOH in particular, the very long time taken for the solubility to converge is attributed to a very slow recrystallization rate. The solid phase collected from the $\mathrm{Cs}_{2}\left[\mathrm{Mo}_{6} \mathrm{Cl}_{14}\right] \cdot \mathrm{H}_{2} \mathrm{O} / 1-\mathrm{PrOH}$ suspension after stirring for $12 \mathrm{~h}$ was sometimes pure-trigonal, while a mixture of the trigonal and monoclinic phases was obtained at other times. Such relatively poor reproducibility is due to the incomplete convergence of the $\left[\mathrm{Mo}_{6} \mathrm{Cl}_{14}\right]^{2-}$ solubility when $1-\mathrm{PrOH}$ was used as solvent. As $\left[\mathrm{Mo}_{6} \mathrm{Cl}_{14}\right]^{2-}$ solubility decreases in moving from $\mathrm{MeOH}$ to $1-\mathrm{PrOH}$, it is likely that the slow recrystallization rate observed for the $\mathrm{Cs}_{2}\left[\mathrm{Mo}_{6} \mathrm{Cl}_{14}\right] \cdot \mathrm{H}_{2} \mathrm{O} / 1$ $\mathrm{PrOH}$ suspension is due to the slow rate of dissolution of $\mathrm{Cs}_{2}\left[\mathrm{Mo}_{6} \mathrm{Cl}_{14}\right] \cdot \mathrm{H}_{2} \mathrm{O}$ into 1-PrOH. Hence, the evolution of $\left[\mathrm{Mo}_{6} \mathrm{Cl}_{14}\right]^{2-}$ solubility corresponds to the recovery from the nonequilibrium state to the equilibrium state in terms of partition coefficient, presumably because the rate of recrystallization is limited by the diffusion of $\left[\mathrm{Mo}_{6} \mathrm{Cl}_{14}\right]^{2-}$ in the solvent.

From the viewport of utilizing this process for practical use, it is worthwhile that the supernatant solution obtained in the recrystallization experiment is reusable. Repeatability depends on the partition coefficient between water, solvents and $\mathrm{Cs}_{2}\left[\mathrm{Mo}_{6} \mathrm{Cl}_{14}\right]$ solids in the suspension. Since the concentration of water in the saturated solution becomes higher every reuse, repetition will be possible until the concentration of water in the reused solution becomes over a limit that can separate pure $\mathrm{Cs}_{2}\left[\mathrm{Mo}_{6} \mathrm{Cl}_{14}\right]$ solids and water. Considering the solvent dependency of the partition coefficient, 1-PrOH will perform better than EtOH. As amount of water molecule is sensitive to water concentration in alcohol as descried in a literature, ${ }^{36,37}$ we have to pay strong attention to water concentration in alcohol when considering reuse of the solvent for purification.

Here, we provide an explanation for why the monoclinic phase crystallizes from $\mathrm{MeOH}$ even when the trigonal-phase precursor is used; we assume that residual water molecules in the $\mathrm{MeOH}$ are trapped in the solid phase to form the monoclinic phase when the solvent dependency of the partition coefficient is considered. The transformation of $80 \mathrm{mg}$ of $\mathrm{Cs}_{2}\left[\mathrm{Mo}_{6} \mathrm{Cl}_{14}\right]$ into $\mathrm{Cs}_{2}\left[\mathrm{Mo}_{6} \mathrm{Cl}_{14}\right] \cdot \mathrm{H}_{2} \mathrm{O}$ requires approximately $0.06 \mathrm{mmol}$ of water. Considering the solubility of $\left[\mathrm{Mo}_{6} \mathrm{Cl}_{14}\right]^{2-}$ in $\mathrm{MeOH}$, more than $0.04 \mathrm{mmol}$ of water is necessary to obtain pure $\mathrm{Cs}_{2}\left[\mathrm{Mo}_{6} \mathrm{Cl}_{14}\right] \cdot \mathrm{H}_{2} \mathrm{O}$ in the suspension made from the $\mathrm{Cs}_{2}\left[\mathrm{Mo}_{6} \mathrm{Cl}_{14}\right]$ precursor and $\mathrm{MeOH}$. Hence, the $\mathrm{MeOH}$ used in this study $(1.0 \mathrm{~mL}$ in volume) must contain $0.04 \mathrm{mmol}$ or more of water, as pure $\mathrm{Cs}_{2}\left[\mathrm{Mo}_{6} \mathrm{Cl}_{14}\right] \cdot \mathrm{H}_{2} \mathrm{O}$ was obtained from the $\mathrm{Cs}_{2}\left[\mathrm{Mo}_{6} \mathrm{Cl}_{14}\right]$ precursor. As the residual concentration of water in commercially available $\mathrm{MeOH}$ is more than this assumed value. ${ }^{38}$ Hence, it is reasonable to attribute the crystallization of $\mathrm{Cs}_{2}\left[\mathrm{Mo}_{6} \mathrm{Cl}_{14}\right] \cdot \mathrm{H}_{2} \mathrm{O}$ from $\mathrm{MeOH}$ to the presence of residual water in the $\mathrm{MeOH}$. In addition, we should mention a possibility that some $\mathrm{MeOH}$ molecules are inserted to the monoclinic phase. Indeed, as indicated in Table S3, the refined lattice parameters of the monoclinic phases collected from $\mathrm{MeOH}$ were likely to be slightly larger than those we previously studied by single-crystal XRD.${ }^{19}$ It is an implication that a part of water molecule of $\mathrm{Cs}_{2}\left[\mathrm{Mo}_{6} \mathrm{Cl}_{14}\right] \cdot \mathrm{H}_{2} \mathrm{O}$ was substituted by $\mathrm{MeOH}$. Thus, the monoclinic phase collected from the $\mathrm{MeOH}$ is considered a water $/ \mathrm{MeOH}$ mixed solvate.

\subsection{Luminescence properties}

On the basis of the discussion presented above, recrystallization from $\mathrm{EtOH}$ or $1-\mathrm{PrOH}$ inhibits the intercalation of water molecules in the $\mathrm{Cs}_{2}\left[\mathrm{Mo}_{6} \mathrm{Cl}_{14}\right]$ lattice even when precursors containing small quantities of water impurities are used, which means that the solvent-mediated purification of $\mathrm{Cs}_{2}\left[\mathrm{Mo}_{6} \mathrm{Cl}_{14}\right]$ can be achieved by employing EtOH or 1-PrOH as the solvent. Subsequent PL and TRPL measurements revealed that the luminescence efficiency of $\mathrm{Cs}_{2}\left[\mathrm{Mo}_{6} \mathrm{Cl}_{14}\right]$ was significantly improved by this purification process, although the PL spectra were almost unchanged by the presence of water molecules. Figure 6(a) compares the PL spectra of the trigonal and monoclinic phases recrystallized from $\mathrm{EtOH}$ and $\mathrm{MeOH}$, respectively, which exhibit peaks centered at $\lambda=764 \mathrm{~nm}$ for the trigonal phase, and $\lambda=768 \mathrm{~nm}$ for the monoclinic phase; these spectral features were retained irrespective of the presence of water molecules in the crystal structure. On the other hand, the TRPL profiles recorded over the 740-800 $\mathrm{nm}$ range (Fig. 6(b)) suggest that the trigonal phases recrystallized from EtOH and 1-PrOH have very similar decay profiles, with relatively longer lifetimes than that of the monoclinic phase recrystallized from $\mathrm{MeOH}$. In addition, the TRPL profile of the trigonal-phase precursor obtained with acetone exhibits relatively fast decay behavior similar to that of the monoclinic phase recrystallized from $\mathrm{MeOH}$. For a quantitative comparison, the decay constants $\left(\tau_{\mathrm{PL}}\right)$ estimated by exponential curve fitting of the TRPL profiles are summarized in Table 2 . The $\tau_{\mathrm{PL}}$ values of the trigonal forms recrystallized from EtOH and 1-PrOH are $\sim 310$ $\mu \mathrm{s}$. In contrast, the $\tau_{\mathrm{PL}}$ value of the monoclinic phase recrystallized from $\mathrm{MeOH}$ is lower, at $184 \mu \mathrm{s}$, and this value is close to that of the trigonal-phase precursor, namely $195 \mu \mathrm{s}$.

It is interesting to note that the monoclinic phase prepared with $\mathrm{MeOH}$ and the trigonal-phase precursor prepared with acetone exhibit very similar behavior and their luminescence lifetimes are much shorter than those of the trigonal phases prepared with EtOH or 1-PrOH. As mentioned, the trigonal precursor has relatively larger unit cell parameters (see Table 1), and this expansion of the trigonal-phase lattice has been attributed to water molecule insertion, as discussed above. Hence, we can safely conclude that the association of water molecule into these $\mathrm{Cs}_{2}\left[\mathrm{Mo}_{6} \mathrm{Cl}_{14}\right]$-based compounds reduces their luminescence lifetimes, and that the enhanced luminescence lifetimes of the trigonal phases obtained with EtOH or 1-PrOH are due to the elimination of inserted water through solvent-mediated purification. In other words, the solvent-mediated purification of $\mathrm{Cs}_{2}\left[\mathrm{Mo}_{6} \mathrm{Cl}_{14}\right]$ via recrystallization from EtOH or 1-PrOH is an appropriate method for improving luminescence efficiency.

\subsection{Electronic structure}

The DFT simulations of both trigonal and monoclinic phases were well converged and the optimized lattice structures of these two compounds are listed in Table S4. Comparisons of 
the data in Tables S1, S2, and S4 reveal that the lattice structures optimized by DFT calculations are comparable to the experimental structures. Hence, these simulations appear to provide sufficient accuracy and are reliable enough for structure-property-relationship discussions. It is notable that the insertion of a water molecule into trigonal $\mathrm{Cs}_{2}\left[\mathrm{Mo}_{6} \mathrm{Cl}_{14}\right]$, to form $\mathrm{Cs}_{2}\left[\mathrm{Mo}_{6} \mathrm{Cl}_{14}\right] \cdot \mathrm{H}_{2} \mathrm{O}$, is calculated to be an exothermic reaction $(16.5 \mathrm{kcal} / \mathrm{mol})$ at sufficiently high water vapor pressure, as evidenced by the difference in the total energies of the trigonal and monoclinic phases.

Figure 7 shows the $E-k$ dispersion of each phase, and the PDOSs corresponding to each band structure is depicted in Fig. S5. The energy band structures shows very small dispersions in $E-k$ space, and the band structures of the trigonal and monoclinic forms are nearly identical, indicating that the electronic state of the $\mathrm{Mo}_{6}$ cluster in the $\left[\mathrm{Mo}_{6} \mathrm{Cl}_{14}\right]^{2-}$ complex, which is considered to play the main role during luminescence, ${ }^{39}$ is highly localized; consequently the presence of water molecules do not cause significant changes in the electronic structure of the $\mathrm{Mo}_{6}$ cluster. As the Mo6 cluster is composed of a cage of fourteen $\mathrm{Cl}^{-}$ions, the electronic structure of the cluster is well screened by the cage. Indeed, the PL spectra of the trigonal and monoclinic phases are very similar to each other, despite the fact that the monoclinic phase contains water molecules in its crystal structure. When we examine the electronic-structural details, there is a clear difference between the trigonal and monoclinic phases, as indicated by the arrows in Fig. 7. It appears that the energy bands near the valence band maximum (VBM) are more localized in the monoclinic phase containing water. This feature is attributed to charge transfer from the water molecule to the Mo6 cluster. The population analysis data listed in Table 3 indicate that the water molecule in the monoclinic phase is slightly negatively charged and this negative charge is compensated for by a decrease in the negative charge on the $\left[\mathrm{Mo}_{6} \mathrm{Cl}_{14}\right]^{2-}$ complex. Hence, the slight differences in the luminescence spectra of the monoclinic and trigonal phases result from slight changes in the electronic structure of the $\left[\mathrm{Mo}_{6} \mathrm{Cl}_{14}\right]^{2-}$ complex that originates from the charge of the water molecule inserted there.

Regarding the TRPL behavior, the calculated results indicate that the presence of water may not be responsible for the observed significant reduction in $\tau_{\text {PL. }}$. Indeed, as shown in Fig. 8, the interatomic distance between $\mathrm{H}$ and $\mathrm{Cl}$ in the assumed structure is $0.23 \mathrm{~nm}$ and the overlap of the $\mathrm{Cl} 2 \mathrm{p}$ and $\mathrm{H} 1 \mathrm{~s}$ orbitals is very small, which means that the probability of electron transfer between $\mathrm{H}$ and $\mathrm{Cl}$ is negligible. However, it should be remembered that thermal vibrations were not considered in the DFT simulations performed in this study. As the TRPL measurements were performed at room temperature, there is a probability that $\mathrm{H}_{2} \mathrm{O}$ interacts with $\mathrm{Cl}$ through thermal vibrations. As the difference between the values of $\tau_{\mathrm{PL}}$ for the water-containing and dehydrated samples is less than a factor of two, this thermal-vibration assumption for the interaction between the $\left[\mathrm{Mo}_{6} \mathrm{Cl}_{14}\right]^{2-}$ complex and water is likely to sufficiently explain the change in $\tau_{\mathrm{PL}}$ observed upon insertion of a water molecule.
At the present time, the non-stoichiometries of these metalcluster-complex-based compounds have not been well investigated. For instance, the substitution of $\mathrm{H}_{3} \mathrm{O}^{+}$ions for $\mathrm{Cs}^{+}$ ions may also possibly degrade luminescence properties. Hence, further detailed characterization of the materials, as well as further simulations that predict possible alternative mechanisms that govern luminescence properties, need to be considered in order to obtain a deeper understanding of the physical and chemical properties of these metal-cluster-complex based compounds. As the highly screened electronic structures of their metal-cluster cores are significant advantages that make these complexes useful in optical applications, further studies that reveal the intrinsic properties of related metal-cluster compounds will provide inspiration for practical engineering applications of these compounds.

\section{Conclusions}

The solvent-mediated purification of trigonal $\mathrm{Cs}_{2}\left[\mathrm{Mo}_{6} \mathrm{Cl}_{14}\right]$ was examined with the aim of obtaining high luminescence efficiency. In particular, we used the hydrophilicities of alcoholic solvents to purify $\mathrm{Cs}_{2}\left[\mathrm{Mo}_{6} \mathrm{Cl}_{14}\right]$ by dehydration. The use of $\mathrm{EtOH}$ and 1-PrOH as the recrystallization solvent resulted in the crystallization of pure trigonal $\mathrm{Cs}_{2}\left[\mathrm{Mo}_{6} \mathrm{Cl}_{14}\right]$, while the use of $\mathrm{MeOH}$ induced the formation of monoclinic $\mathrm{Cs}_{2}\left[\mathrm{Mo}_{6} \mathrm{Cl}_{14}\right] \cdot \mathrm{H}_{2} \mathrm{O}$. This crystallization behavior is explained by assuming different partition coefficients between water and the various alcohols. We demonstrated that $\mathrm{EtOH}$ and 1-PrOH, particularly 1-PrOH, behave as dehydrating agents by trapping water molecules during the recrystallization process. On the other hand, $\mathrm{MeOH}$ works as a hydrating agent by providing residual water that intercalates into $\mathrm{Cs}_{2}\left[\mathrm{Mo}_{6} \mathrm{Cl}_{14}\right]$. Characterization of the resultant powders by XRD, TDS and FT-IR techniques reveal that recrystallization from 1-PrOH is an efficient way of purifying the trigonal phase. Finally, improvements in luminescence efficiency through dehydration were confirmed by TRPL experiments in which the trigonal phase purified in EtOH or 1-PrOH exhibited much longer luminescence lifetimes than the compounds contaminated by water. Hence, we conclude that $1-\mathrm{PrOH}$ is a very useful solvent for the recrystallization of high purity $\mathrm{Cs}_{2}\left[\mathrm{Mo}_{6} \mathrm{Cl}_{14}\right]$. The enhancement in luminescence efficiency through the purification procedure demonstrated in this study encourages the further development of metal-cluster-complex-based compounds for optoelectronic applications.

\section{Acknowledgements}

This work was carried out as part of the France-Japan international collaboration framework (UMI 3629-LINK Center). The authors thank people involved in LINK and related activities, particularly Drs. David Lechevalier and Mari Kono of Saint-Gobain KK (Tokyo, Japan) for their efforts on international communication and project management, Noée Dumait, Serge Paofai of ISCR for their contributions to contributions to the synthesis of metal clusters precursors. N.S. 
would also like to thank Prof. Junzo Tanaka of Tokyo Tech for support and encouragement. The study was financially supported by Saint-Gobain Co. Ltd. (Paris, France), NIMS, CNRS, Université de Rennes 1, Region Bretagne (France), and Fondation Langlois.

\section{References}

1 J. A. Christians, P. A. M. Herrera, P. V. Kamat, Transformation of the Excited State and Photovoltaic Efficiency of $\mathrm{CH}_{3} \mathrm{NH}_{3} \mathrm{PbI}_{3}$ Perovskite upon Controlled Exposure to Humidified Air., J. Am. Chem. Soc., 2015, 137, 1530-1538.

2 I. C. Smith, E. T. Hoke, D. Solis-Ibarra, M. D. McGehee, H. I. Karunadasa, A Layered Hybrid Perovskite Solar-Cell Absorber with Enhanced Moisture Stability., Angew. Chem. 2014, 126, 11414-11417.

3 T. Miyase, K. Watanabe, I. Sakaguchi, N. Ohashi, K. Domen, K. Nomura, H. Hiramatsua, H. Kumomi, H. Hosono, T. Kamiya, Roles of Hydrogen in Amorphous Oxide Semiconductor In-Ga-Zn-O: Comparison of Conventional and Ultra-High-Vacuum Sputtering., ECS J. Solid State Sci. Technol., 2014, 3, Q3085-Q3090.

4 K. Watanabe, M. Hashiguchi, I. Sakaguchi, A. Bryant, Y. Adachi, Y. Zhen, T. Ohgaki, T. Ohsawa, H. Haneda, N Ohashi, Hydrogen in Tin Dioxide Films and Bulk Ceramics: An Attempt to Identify the Most Hidden Impurity., Appl. Phys. Lett., 2014, 104, 042110-1-4.

5 A. Simon, Clusters of Valence Electron Poor MetalsStructure, Bonding, and Properties., Angew. Chem. Int. Ed. Engl., 1988, 27, 159-183.

6 A. Perrin, C. Perrin, M. Sergent, Octahedral Clusters in Molybdenum(II) and Rhenium(III) Chalcohalide Chemistry., J. Less-Common Met., 1988, 137, 241-265.

7 A. Perrin, C. Perrin, The Molybdenum and Rhenium Octahedral Cluster Chalcohalides in Solid State Chemistry: From Condensed to Discrete Cluster Units., C. R. Chim., 2012, 15, 815-836.

8 Y. Kim, V. E. Fedorov, S.-J. Kim, Novel Compounds Based on $\left[\operatorname{Re}_{6} \mathrm{Q}_{8}(\mathrm{~L})_{6}\right]^{4-}(\mathrm{Q}=\mathrm{S}, \mathrm{Se}, \mathrm{Te} ; \mathrm{L}=\mathrm{CN}, \mathrm{OH})$ and Their Applications., J. Mater. Chem., 2009, 19, 7178-7190.

9 S. Ababou-Girard, S. Cordier, B. Fabre, Y. Molard, C. Perrin, Assembly of Hexamolybdenum Metallic Clusters on Silicon Surfaces., ChemPhysChem, 2007, 14, 2086-2090.

10 Y. Molard, C. Labbé, J. Cardin, S. Cordier, Sensitization of $\mathrm{Er}^{3+}$ Infrared Photoluminescence Embedded in a Hybrid Organic-Inorganic Copolymer Containing Octahedral Molybdenum Clusters., Adv. Funct. Mater., 2013, 23, 48214825.

11 M. Amela-Cortes, A. Garreau, S. Cordier, E. Faulques, J.-L. Duvail, Y. Molard, Deep Red Luminescent Hybrid Copolymer Materials with High Transition Metal Cluster Content., J. Mater. Chem. C., 2014, 2, 1545-1552.

12 W. Preetz, K. Harder, H. G. von Schnering, G. Kliche, K. Peters, Synthesis, Structure and Properties of the Cluster Anions $\left[\left(\mathrm{Mo}_{6} \mathrm{Cl}_{8}^{\mathrm{i}}\right) \mathrm{X}_{6}^{\mathrm{a}}\right]^{2-}$ with $\mathrm{X}^{\mathrm{a}} \equiv \mathrm{F}, \mathrm{Cl}, \mathrm{Br}$, I., J. Alloy Compd., 1992, 183, 413-429.

13 W. Preetz, D. Bublitz, H. G. von Schnering, J. Saßmannshausen, Darstellung, Kristallstruktur und spektroskopische Eigenschaften der Clusteranionen $\left[\left(\mathrm{Mo}_{6} \mathrm{Br}^{\mathrm{i}}{ }_{8}\right) \mathrm{X}_{6}^{\mathrm{a}}\right]^{2-}$ mit $\mathrm{X}^{\mathrm{a}}=\mathrm{F}, \mathrm{Cl}, \mathrm{Br}, \mathrm{I} .$, Z. Anorg. Allg. Chem., 1994, 620, 234-246.

14 P. Brückner, W. Preetz, M. Pünjer, Darstellung, Kristallstrukturen, NMR-, Schwingungsspektren und Normalkoordinatenanalyse der Clusteranionen $\left[\left(\mathrm{Mo}_{6} \mathrm{I}_{8}{ }^{\mathrm{i}}\right) \mathrm{Y}^{\mathrm{a}}{ }_{6}\right]^{2-}$, $\mathrm{Y}^{\mathrm{a}}=\mathrm{F}, \mathrm{Cl}$, Br, I. Z., Anorg. Allg. Chem., 1997, 623, 8-17.
15 A. W. Maverick, J. S. Najdzionek, D. MacKenzie, D. G. Nocera, H. B. Gray, Spectroscopic, Electrochemical, and Photochemical Properties of Molybdenum(II) and Tungsten(II) Halide Clusters., J. Am. Chem. Soc., 1983, 105, $1878-1882$

16 A. W. Maverick, H. B. Gray, Luminescence and Redox Photochemistry of the Molybdenum(II) Cluster $\mathrm{Mo}_{6} \mathrm{Cl}_{14}{ }^{2-}$., $J$. Am. Chem. Soc., 1981, 103, 1298-1300.

17 M. A. Mikhailov, K. A. Brylev, P. A. Abramov, E. Sakuda, S. Akagi, A. Ito, N. Kitamura, M. N. Sokolov, Synthetic Tuning of Redox, Spectroscopic, and Photophysical Properties of $\left\{\mathrm{Mo}_{6} \mathrm{I}_{8}\right\}^{4+}$ Core Cluster Complexes by Terminal Carboxylate Ligands, Inorg. Chem., 2016, 55, 8437-8445.

18 N. Saito, Y. Wada, P. Lemoine, S. Cordier, F. Grasset, T. Ohsawa, N. Saito, J. S. Cross, N. Ohashi, Theoretical and Experimental Determination of the Crystal Structures of Cesium-Molybdenum Chloride., Jpn. J. Appl. Phys., 2016, 55, 075502-1-8.

19 N. Saito, P. Lemoine, N. Dumait, M. Amela-Cortes, S. Paofai, T. Roisnel, V. Nassif, F. Grasset, N. Ohashi, S. Cordier, From $\mathrm{Cs}_{2} \mathrm{Mo}_{6} \mathrm{Cl}_{14}$ to $\mathrm{Cs}_{2} \mathrm{Mo}_{6} \mathrm{Cl}_{14} \cdot \mathrm{H}_{2} \mathrm{O}$ and Vice Versa: Crystal Chemistry Investigations., J. Clust. Sci., 2017, 28, 773-798.

20 K. Kirakci, S. Cordier, C. Perrin, Synthesis and Characterization of $\mathrm{Cs}_{2} \mathrm{Mo}_{6} \mathrm{X}_{14} \quad(\mathrm{X}=\mathrm{Br}$ or $\mathrm{I})$ Hexamolybdenum Cluster Halides: Efficient Mo6 Cluster Precursors for Solution Chemistry Syntheses., Z. Anorg. Allg. Chem., 2005, 631, 411-416.

21 P. C. Healy, D. L. Kepert, D. Taylor, A. H. White, Crystal Structure of Dicaesium Octa- $\mu 3$-Chloro-HexachloroOctahedro-Hexa-Tungstate(II) and -Molybdate(II) Complexes., J. Chem. Soc., Dalton Trans., 1973, 6, 646-650.

22 M. Potel, C. Perrin, A. Perrin, M. Sergent, New Families of Ternary Molybdenum (II) Chlorides with Octahedral Mo6 Clusters., Mat. Res. Bull., 1986, 21, 1239-1245.

23 F. W. Koknat, T. J. Adaway, S. I. Erzerum, S. Syed, Convenient Synthesis of the Hexanuclear Molybdenum(II) Halides $\mathrm{Mo}_{6} \mathrm{Cl}_{12}$ and $\mathrm{Mo}_{6} \mathrm{Br}_{12} \cdot 2 \mathrm{H}_{2} \mathrm{O}$., Inorg. Nucl. Chem. Lett., 1980, 16, 307-310.

24 F. Izumi, T. Ikeda, A Rietveld-Analysis Program RIETAN-98 and its Applications to Zeolites., Mater. Sci. Forum, 2000, 321-324, 198-203.

25 J. P. Perdew, A. Ruzsinszky, L. G. I. Csonka, O. A. Vydrov, G. E. Scuseria, L. A. Constantin, X. Zhou, K. Burke, Restoring the Density-Gradient Expansion for Exchange in Solids and Surfaces., Phys. Rev. Lett., 2008, 100, 136406-14

26 S. J. Clark, M .D. Segall, C. J. Pickard, P. J. Hasnip, M. J. Probert, K. Refson, M. C. Payne, First Principles Methods Using CASTEP. Z. Kristallogr., 2005, 220, 567-570.

27 N. Saito, S. Cordier, P. Lemoine, T. Ohsawa, Y. Wada, F. Grasset, J. S. Cross, N. Ohashi, Lattice and Valence Electronic Structures of Crystalline Octahedral Molybdenum Halide Clusters-Based Compounds, $\mathrm{Cs}_{2}\left[\mathrm{Mo}_{6} \mathrm{X}_{14}\right](\mathrm{X}=\mathrm{Cl}, \mathrm{Br}$, I), Studied by Density Functional Theory Calculations., Inorg Chem., 2017, 56, 6234-6243.

28 D. D. Koelling, B. N. Harmon, A Technique for Relativistic Spin-Polarised Calculations., J. Phys. C: Solid State Phys., 1977, 10, 3107-3114.

29 M. S. B. Munson, F. H. Field, Chemical Ionization Mass Spectrometry. I. General Introduction., Phys. Inorg. Chem., 1966, 88, 2621-2630.

30 H. D. Lutz, H. Christian, Raman and Infrared Spectra of Barium and Strontium Halide Monohydrates, $\mathrm{MX}_{2} \bullet 1 \mathrm{H}_{2} \mathrm{O}(\mathrm{M}$ $=\mathrm{Ba}, \mathrm{Sr} ; \mathrm{X}=\mathrm{Cl}, \mathrm{Br}, \mathrm{I})$. A New Interpretation of the Frequency Shiftings of $\mathrm{OH}$ Stretching Modes in Solid Hydrates., J. Mol. Struct., 1982, 96, 61-72. 
31 G. J. Kubas, C. J. Burns, G. R. K. Khalsa, L. S. Van Der Sluys, G. Kiss, C. D. Hoff, Dihydrogen: A Better Ligand Than Water? IR and X-ray Evidence for Aquo Coordination in $\mathrm{W}(\mathrm{CO})_{3}\left(\mathrm{PR}_{3}\right)_{2}\left(\mathrm{H}_{2} \mathrm{O}\right)$, Thermodynamics of $\mathrm{H}_{2} \mathrm{O}$ Binding versus .eta. 2- $\mathrm{H}_{2}$ Binding and $\mathrm{H}_{2} \mathrm{O} / \mathrm{D}_{2}$ Isotopic Exchange. Implications for the Biological Activation of Hydrogen., Organometallics, 1992, 11, 3390-3404.

32 E. K. Plyler, Infrared Spectra of Methanol, Ethanol, and nPropanol., J. Res. Natl. Bur. Stand., 1952, 48, 281-286.

33 K. Inumaru, A. Anzai, T. Kikudome, M. Harada, H. Sakai, Y. Ide, T. Sano, S. Yamanaka, Molybdenum Cluster Halide Compound $\mathrm{Mo}_{6} \mathrm{Cl}_{12}\left(\mathrm{OH}_{2}\right)_{2}$ with Six-Handed Linkage Hydrogen Bonding., Bull. Chem. Soc. Jpn., 2011, 84, 379385.

34 R. W. Larsen, P. Zielke, M. A. Suhm, Hydrogen-Bonded OH Stretching Modes of Methanol Clusters: A Combined IR and Raman Isotopomer Study., J. Chem. Phys., 2007, 126, 194307-1-18.

35 K. Watanabe, I. Sakaguchi, M. Hashiguchi, N. Saito, E. M. Ross, H. Haneda, T. Ohsawa, N. Ohashi, Isotope Tracer Investigation and Ab-initio Simulation of Anisotropic
Hydrogen Transport and Possible Multi-Hydrogen Centers in Tin Dioxide., J. Appl. Phys., 2016, 119, 225704-1-10.

36 A. Flemström, T. K. Hirsch, L. Eriksson, S. Lidin, The structures of $\mathrm{X}_{2}\left[\left(\mathrm{Mo}_{6} \mathrm{Cl}_{8}\right) \mathrm{Cl}_{6}\right] \cdot n \mathrm{H}_{2} \mathrm{O}, \mathrm{X}=\mathrm{NH}_{4}, \mathrm{~K}, \mathrm{Rb}, \mathrm{Cs}$., Solid State Sci., 2004, 6, 509-517.

37 A. Flemström, T. K. Hirsch, L. Sehlsedt, S. Lidin, L. Ojamäe, Effects from hydrogen bonds on water structure in $\left(\mathrm{H}_{3} \mathrm{O}\right)_{2}\left[\mathrm{Mo}_{6} \mathrm{Cl}_{8} \mathrm{X}_{6}\right] \cdot y \mathrm{H}_{2} \mathrm{O} \mathrm{X}=\mathrm{Cl}(y=7), \mathrm{Br}(y=6)$, or $\mathrm{I}(y=6)$., Solid State Sci., 2002, 4, 1017-1022.

38 D. R. Burfield, R. H. Smithers, Desiccant Efficiency in Solvent and Reagent Drying. 7. Alcohols., J. Org. Chem., 1983, 48, 2420-2422.

39 K. Costuas, A. Garreau, A. Bulou, B. Fontaine, J. Cuny, R. Gautier, M. Mortier, Y. Molard, J. L. Duvail, E. Faulques, S. Cordier, Combined Theoretical and Time-Resolved Photoluminescence Investigations of $\left[\mathrm{Mo}_{6} \mathrm{Br}^{\mathrm{i}}{ }_{8} \mathrm{Br}_{6}^{\mathrm{a}}\right]^{2-}$ Metal Cluster Units: Evidence of Dual Emission., Phys. Chem. Chem. Phys., 2015, 17, 28574-28585. 


\section{Figures}

(a)

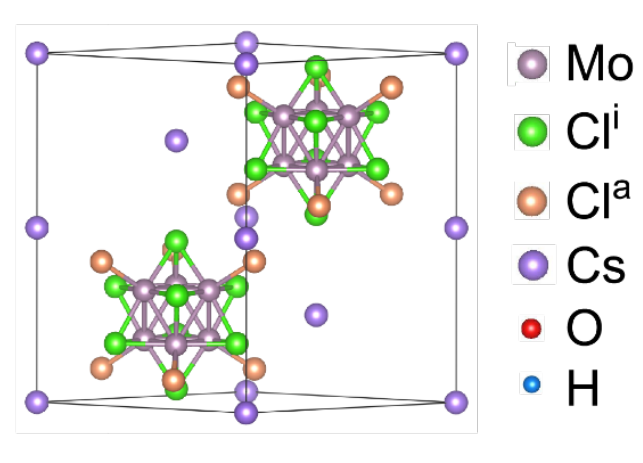

(b)

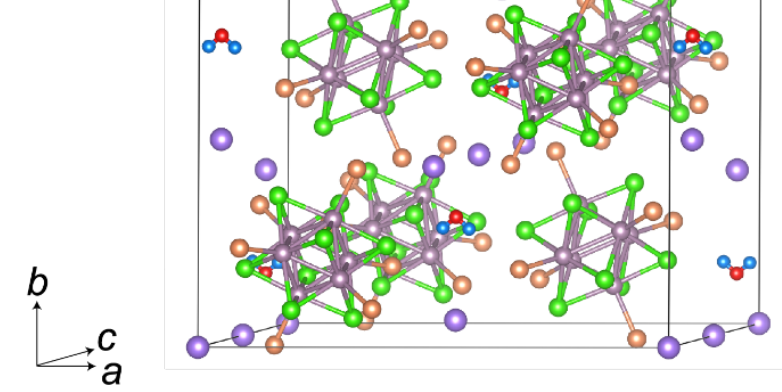

Figure 1 Schematic illustration of the crystal structures of (a) $\mathrm{Cs}_{2}\left[\mathrm{Mo}_{6} \mathrm{Cl}_{14}\right]$ and (b) $\mathrm{Cs}_{2}\left[\mathrm{Mo}_{6} \mathrm{Cl}_{14}\right] \cdot \mathrm{H}_{2} \mathrm{O}$. 

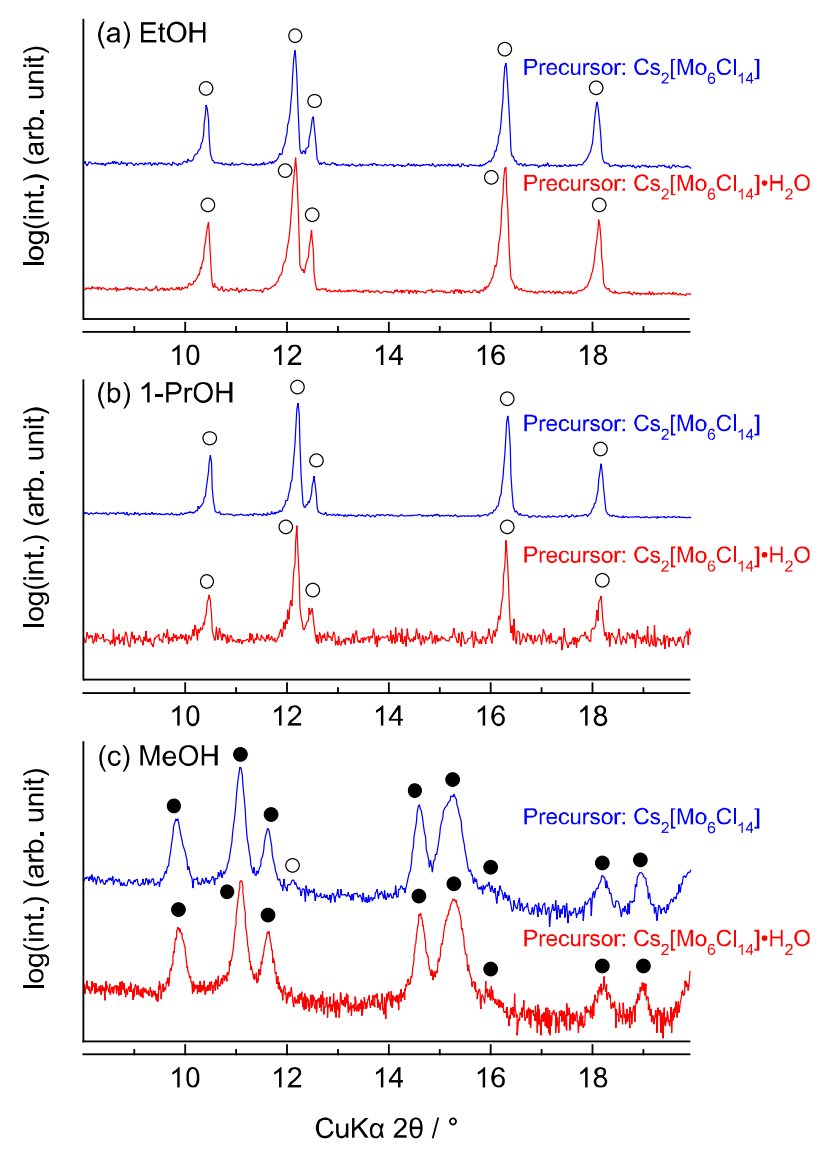

Figure 2 XRD patterns of the powder collected from the suspensions prepared using two different precursors, i.e., monoclinic-phase $\mathrm{Cs}_{2}\left[\mathrm{Mo}_{6} \mathrm{Cl}_{14}\right] \cdot \mathrm{H}_{2} \mathrm{O}$ and trigonal-phase $\mathrm{Cs}_{2}\left[\mathrm{Mo}_{6} \mathrm{Cl}_{14}\right]$, and three different solvents: (a) EtOH, (b) 1-PrOH, and (c) MeOH. The open and closed circles indicates XRD peak from the trigonal and monoclinic phase, respectively. 


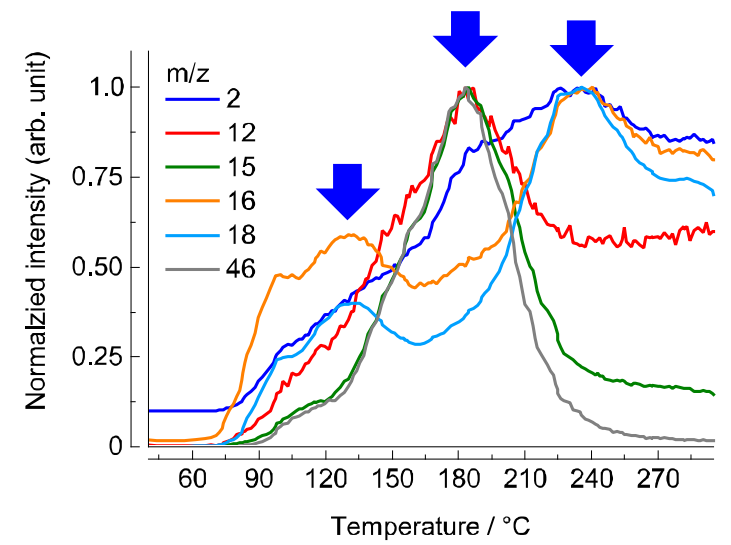

Figure 3 Normalized TDS spectra of the trigonal forms collected from EtOH suspension using $\mathrm{Cs}_{2}\left[\mathrm{Mo}_{6} \mathrm{Cl}_{14}\right] \cdot \mathrm{H}_{2} \mathrm{O}$ as precursor. Arrows indicate characteristic desorption peaks. 

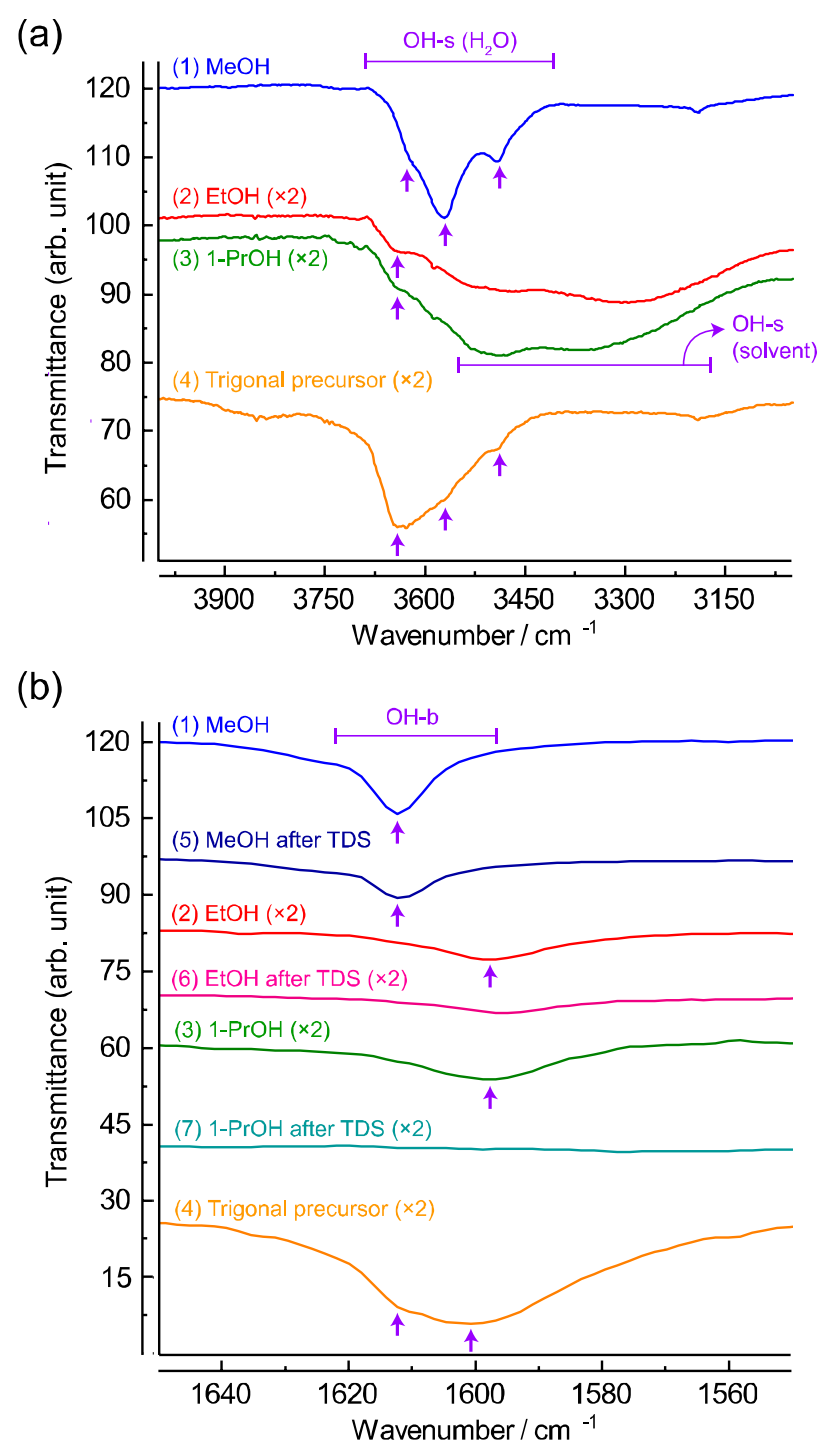

Figure 4 FT-IR spectra of different precursors and recrystallized samples in the (a) $\mathrm{OH}$ stretching $(\mathrm{OH}-\mathrm{s})$ mode and (b) $\mathrm{OH}$ bending $(\mathrm{OH}-\mathrm{b})$ mode regions. The spectra were obtained by using (1) monoclinic phase crystallized in $\mathrm{MeOH}$, trigonal form crystallized in (2) EtOH or (3) 1-PrOH, and (4) trigonal-form precursor crystallized in acetone solvent. The spectra (5)-(7) indicate the sample (1)-(3) heated in vacuum condition through the TDS measurements, respectively. Arrows indicate characteristic peaks associated with the presence of water. 


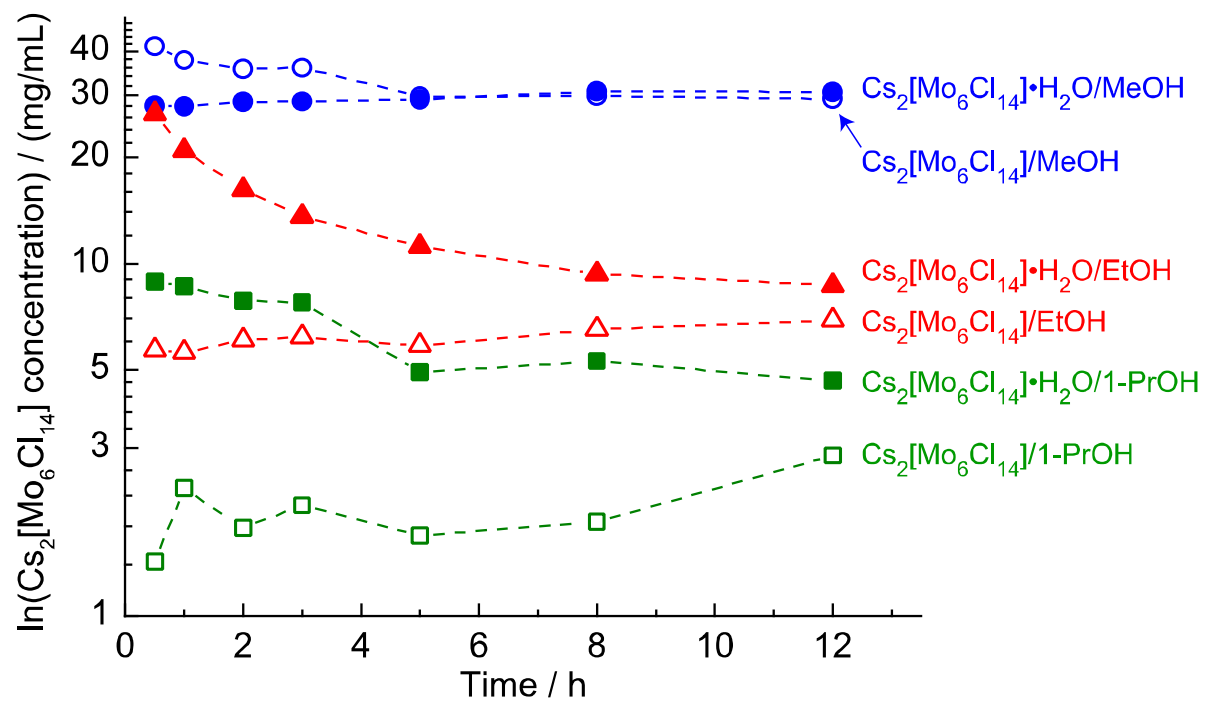

Figure 5 Time evolution of $\mathrm{Cs}_{2}\left[\mathrm{Mo}_{6} \mathrm{Cl}_{14}\right]$ concentration in the supernatant of the suspensions with different precursor/solvent combinations. The open and closed symbols are for combinations with $\mathrm{Cs}_{2}\left[\mathrm{Mo}_{6} \mathrm{Cl}_{14}\right]$ and $\mathrm{Cs}_{2}\left[\mathrm{Mo}_{6} \mathrm{Cl}_{14}\right] \cdot \mathrm{H}_{2} \mathrm{O}$ precursors, respectively. 

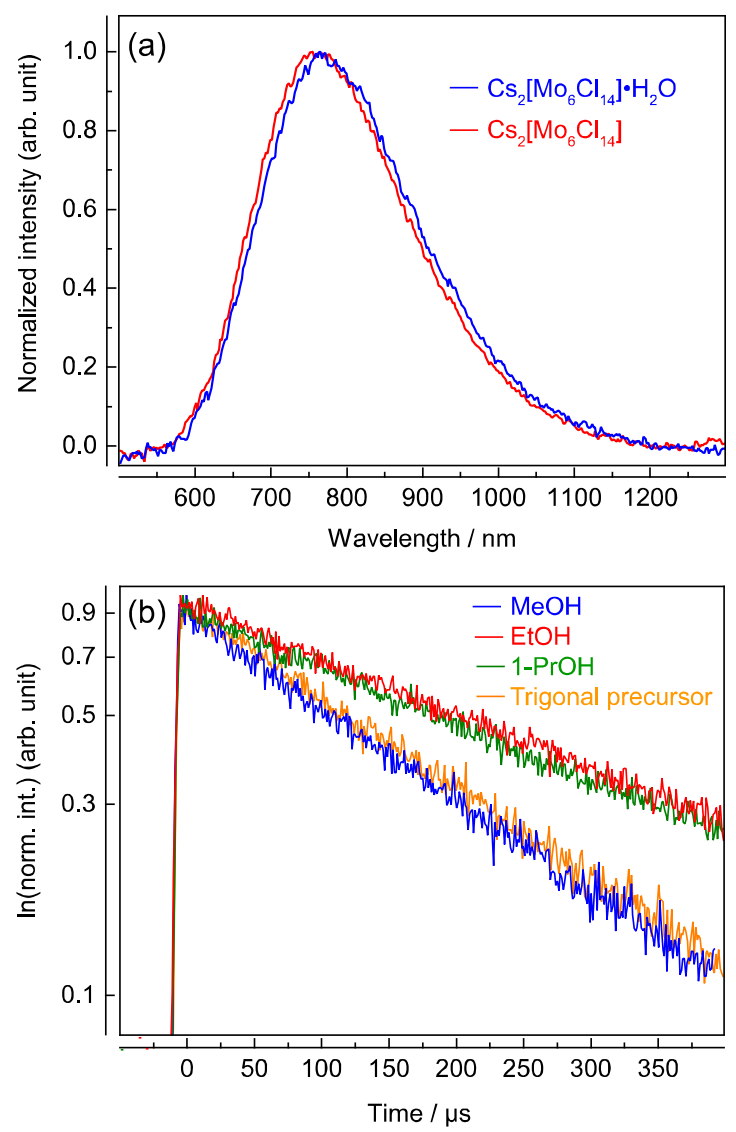

Figure 6 (a) PL spectra of the trigonal-phase precursor and recrystallized trigonal-form $\mathrm{Cs}_{2}\left[\mathrm{Mo}_{6} \mathrm{Cl}_{14}\right]$ and monoclinic-form $\mathrm{Cs}_{2}\left[\mathrm{Mo}_{6} \mathrm{Cl}_{14}\right] \cdot \mathrm{H}_{2} \mathrm{O}$, and (b) TRPL spectra of the trigonal-phase precursor and the samples recrystallized with $\mathrm{MeOH}, \mathrm{EtOH}$ or 1-PrOH. 


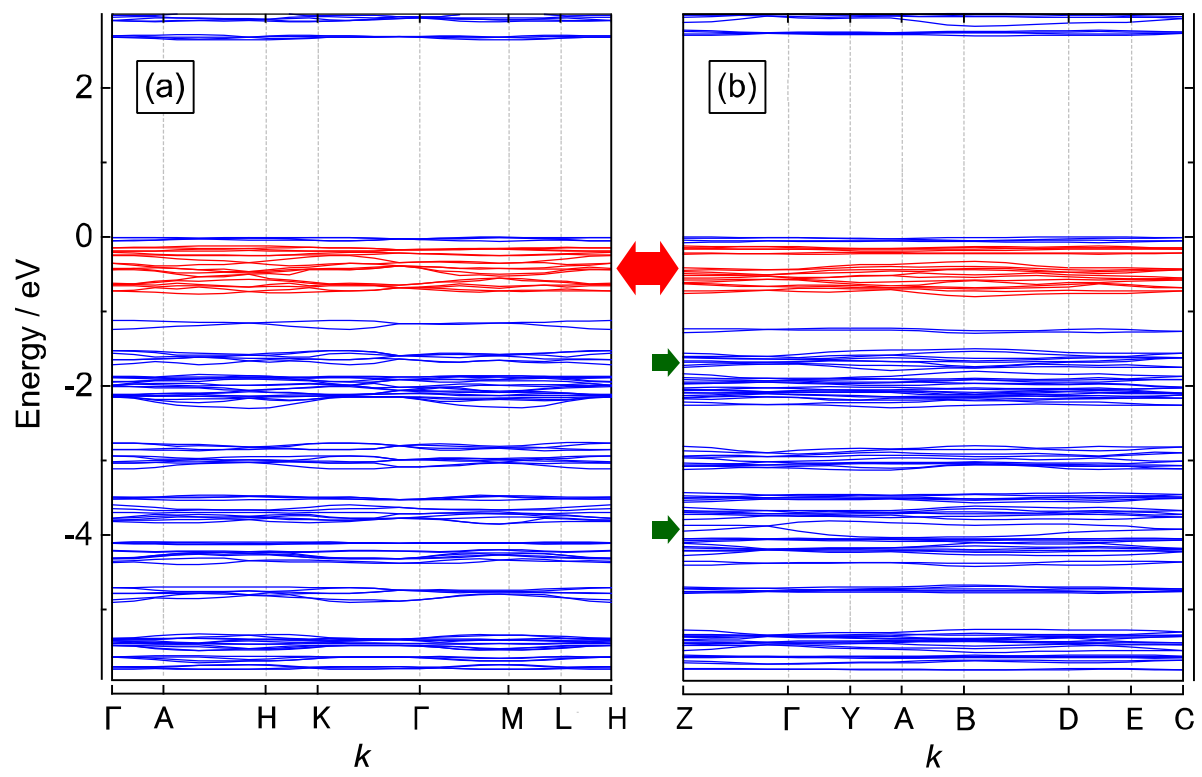

Figure 7 Energy band structure of (a) trigonal $\mathrm{Cs}_{2}\left[\mathrm{Mo}_{6} \mathrm{Cl}_{14}\right]$ and (b) monoclinic $\mathrm{Cs}_{2}\left[\mathrm{Mo}_{6} \mathrm{Cl}_{14}\right] \cdot \mathrm{H}_{2} \mathrm{O}$. Difference between $E-k$ dispersion of these compounds can be found in the energy range indicated by a red arrow, and the water related electronic states exist at the energy ranges indicated by two green arrows. 


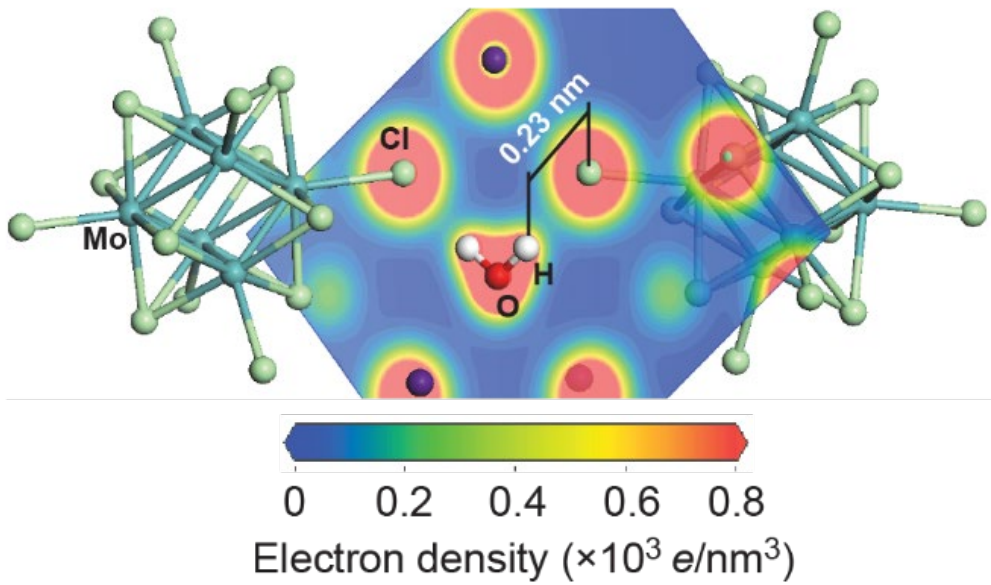

Figure 8 Contour map of electron density around the inserted $\mathrm{H}_{2} \mathrm{O}$ molecule in $\mathrm{Cs}_{2}\left[\mathrm{Mo}_{6} \mathrm{Cl}_{14}\right] \cdot \mathrm{H}_{2} \mathrm{O}$. 
Table 1 Refined lattice parameters $(a$ and $c$ ) and unit cell volume $(V)$ of the trigonal-phase samples prepared with different combination of precursor and solvent.

\begin{tabular}{ccccc}
\hline \multirow{2}{*}{ Precursor } & \multirow{2}{*}{ Solvent } & \multicolumn{3}{c}{ Lattice parameters } \\
& & $a / \mathrm{nm}$ & $c / \mathrm{nm}$ & $V / \mathrm{nm}^{3}$ \\
\hline $\mathrm{Cs}_{2}\left[\mathrm{Mo}_{6} \mathrm{Cl}_{14}\right]$ & $\mathrm{EtOH}$ & $0.9815(2)$ & $1.4161(3)$ & $1.1814(4)$ \\
$\mathrm{Cs}_{2}\left[\mathrm{Mo}_{6} \mathrm{Cl}_{14}\right] \cdot \mathrm{H}_{2} \mathrm{O}$ & $\mathrm{EtOH}$ & $0.9792(3)$ & $1.4213(3)$ & $1.1801(5)$ \\
$\mathrm{Cs}_{2}\left[\mathrm{Moo}_{6} \mathrm{Cl}_{14}\right]$ & $1-\mathrm{PrOH}$ & $0.9783(3)$ & $1.4183(4)$ & $1.1756(6)$ \\
$\mathrm{Cs}_{2}\left[\mathrm{Mo}_{6} \mathrm{Cl}_{14}\right] \cdot \mathrm{H}_{2} \mathrm{O}$ & $1-\mathrm{PrOH}$ & $0.9783(3)$ & $1.4218(3)$ & $1.1785(6)$ \\
Precursor purified with acetone & $0.9820(2)$ & $1.4200(4)$ & $1.1860(4)$ \\
\hline
\end{tabular}

Table 2 Luminescence lifetime $\left(\tau_{\mathrm{PL}}\right)$ of different precursors and recrystallized samples.

\begin{tabular}{ccc}
\hline Solvent & Obtained phase & $\tau_{\mathrm{PL}} / \mu \mathrm{s}$ \\
\hline Acetone & Trigonal + Monoclinic & 195 \\
$\mathrm{MeOH}$ & Monoclinic & 184 \\
EtOH & Trigonal & 316 \\
1-PrOH & Trigonal & 310 \\
\hline
\end{tabular}

Table 3 Results of population analyses for trigonal $\mathrm{Cs}_{2}\left[\mathrm{Mo}_{6} \mathrm{Cl}_{14}\right]$, and monoclinic $\mathrm{Cs}_{2}\left[\mathrm{Mo}_{6} \mathrm{Cl}_{14}\right] \cdot \mathrm{H}_{2} \mathrm{O}$.

\begin{tabular}{cccc}
\hline Molecule & Form & Mulliken & Hirshfeld \\
\hline \multirow{2}{*}[\mathrm{Mo}_{6}\mathrm{Cl}_{14}]{} & Trigonal & $-1.94 e$ & $-0.44 e$ \\
& Monoclinic & $-1.78 e$ & $-0.38 e$ \\
$\mathrm{H}_{2} \mathrm{O}$ & Trigonal & N/A & N/A \\
& Monoclinic & $-0.11 e$ & $-0.08 e$ \\
\hline
\end{tabular}




\section{CrystEngComm}

For Table Contents Entry

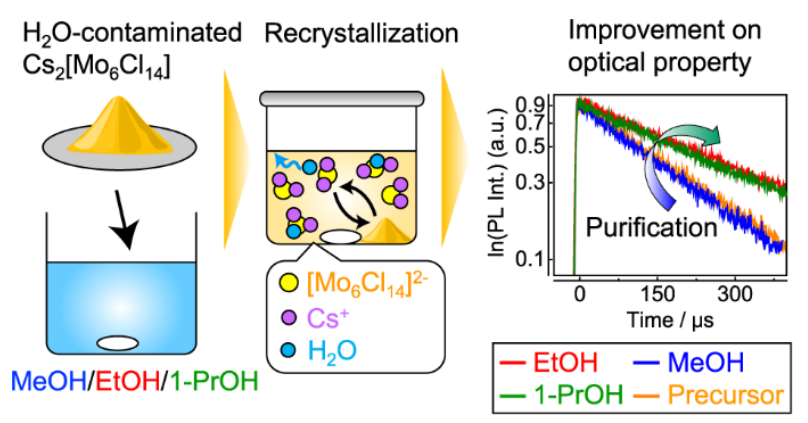

An octahedral molybdenum cluster compound, $\mathrm{Cs}_{2}\left[\mathrm{Mo}_{6} \mathrm{Cl}_{14}\right]$, was purified by recrystallization with hydrophilic alcohol solvents for enhancing its luminescence efficiency. 